\title{
WPLYW IMPLEMENTACJI ZASAD 5S NA DOSKONALENIE PROCESÓW MAGAZYNOWYCH W WYBRANEJ ORGANIZACJI
}

\begin{abstract}
Obecnie przedsiębiorcy mają możliwość korzystania z wielu metod i narzędzi zarządzania jakością, usprawniających zarówno działania logistyczne, jak i produkcyjne - jedną $\mathrm{z}$ godnych uwagi jest bezsprzecznie koncepcja $5 \mathrm{~S}$. Ideą $5 \mathrm{~S}$ jest zaprowadzenie $\mathrm{i}$ utrzymanie porządku i dyscypliny w miejscu (na stanowisku) pracy. Praktyki 5S są jednym z fundamentów tworzenia środowiska pracy sprzyjającego działaniom projakościowym, harmonijnej pracy i ciągłemu doskonaleniu stosunków ludzkich, co przekłada się na efektywność organizacji. Zdaniem jej zwolenników 5S jest jednym z najważniejszych elementów dobrego zarządzania. Celem niniejszej publikacji jest ukazanie, w jakim stopniu implementacja zasad 5S może wpłynąć na usprawnienie działań logisty cznych w obszarze zarządzania magazynem w wybranej organizacji produkcyjnej. Dokonując analizy literatury oraz badając proces implementacji zasad 5S w wybranej organizacji, stwierdzono, że implementacja zasad $5 \mathrm{~S}$ w przedsiębiorstwie nie wy maga duży ch nakładów. Jest to sy stem prosty i zrozumiały, a wprowadzony porządek w krótkim czasie może przynieść wy mierne korzy ści. Do najczęściej zauważanych korzyści, które wynikają z wdrożenia zasad 5S zalicza się: usprawnienie procesów i płynności pracy, wzrost terminowości, redukcję zbędnych działań, poprawę higieny i bezpieczeństwa pracy, usprawnienie komunikacji, redukcję liczby defektów i wypadków. Podkreślono również, że implementacja zasad 5S musi być przez pierwsze lata stale monitorowana i doskonalona. Dlatego bardzo istotna jest kwestia nadzoru oraz działan moty wacy jny ch szczególnie ze strony liderów i kierownictwa organizacji.
\end{abstract}

Slowa kluczowe: 5S, jakość, logistyka, instrumenty

\section{WPROWADZENIE}

Logistyka jest takim obszarem przedsiębiorstwa, w którym przenikają się, wspierają i uzupełniają rozmaite koncepcje zarządzania. W związku z tym skuteczne i efektywne zarządzanie logistyką wymaga od osób sprawujących stanowiska kierownicze stosowania instrumentów zarządzania, które mogą wspierać i udoskonalać procesy logistyczne. Zdaniem autorów szczególnie istotne z punktu widzenia doskonalenia procesów logistycznych są systemy, zasady i koncepcje zarządzania jakością. W podobnym tonie wypowiada się Marek Ciesielski ${ }^{4}$, który podkreśla, że jedną z podstawowych determinant sprawnego

\footnotetext{
${ }^{1}$ Dr Dominik Zimon, Katedra SystemówZarządzania i Logistyki, Politechnika Rzeszowska, Al. Powstańców Warszawy 8, 35-959Rzeszów, tel.; (17) 86510 73, e-mail: zdomin@prz.edu.pl. (autor korespondencyjny)

${ }^{2}$ Dr. h.c., Prof. Ing. Dušan Malindžák, Katedra SystemówZarządzania i Logistyki, Politechnika Rzeszowska, e-mail: dusanm@prz.edu.pl

${ }^{3}$ Mgr. inż. Karolina Kolbusz, Nowy Styl Group

${ }^{4}$ M. Ciesielski, Instrumenty zarzadzania łańcuchami dostaw, PWE, Warszawa 2009, s. 31.
} 
funkcjonowania procesów logistycznych jest zachowanie odpowiednich standardów jakościowych. Zarządzanie jakością w logistyce nie może bazować na przypadkowych i fragmentarycznych działaniach, lecz musi być starannie zaprojektowane i wdrożone w oparciu na metodyce zarządzania jakością. Dlatego niezwykle istotne jest posiłkowanie się instrumentami zarządzania jakością, które służą określaniu i porządkowaniu przyczyn problemów występujących w przedsiębiorstwach i ponadto umożliwiają poznanie źródeł niezgodności i niepożądanych zdarzeń oraz wskazanie tych spośród nich, które powinny być przedmiotem dalszej analizy i działań zmierzających do korygowania i doskonalenia praktyk przyjętych w organizacji ${ }^{5}$. Podkreślić należy, że wspieranie działań logistycznych wytycznymi zawartymi w nowoczesnych koncepcjach i zasadach zarządzania jakością przynosi obopólną korzyść w postaci efektywniejszych działań logistycznych ${ }^{6}$, pełniejszej obsługi klienta oraz realizowaniu procesów produkcyjnych i usługowych o wyższych standardach jakości.

Według Jerzego Lunarskiego ${ }^{7}$ istnieje wiele charakterystycznych metod i narzędzi zarządzania jakością usprawniających zarówno działania logistyczne, jak i produkcyjne jedną z nich jest bezsprzecznie koncepcja 5S. Celem niniejszej publikacji jest ukazanie, w jakim stopniu implementacja zasad 5S może wpłynąć na usprawnienie działań logistycznych w obszarze zarządzania magazynem w wybranej organizacji produkcyjnej.

\section{ZASADY 5S - INFORMACJE WSTEPNE}

Specjaliści z dziedziny zarządzania jakością uważają 5S za znakomitą metodę, która prowadzi do uzyskania bezpiecznych, czystych oraz wydajnych stanowisk pracy, sprzyjających większej produktywności, stabilizacji procesów, minimalizacji błędów oraz wdrażaniu działań projakościowych ${ }^{8}$.

Zasady 5S to odpowiednio: Seri, Seito, Seiso, Seiketsu, Shitsuke, którym odpowiadają następujące słowa w języku polskim: Selekcja, Systematyka, Sprzątanie, Standaryzacja, Samodyscyplina. Interpretacja poszczególnych zasad jest następująca ${ }^{9}$ :

- $\quad$ selekcja - eliminacja rzeczy niepotrzebnych i nieużywanych, usunięcie narzędzi, części, dokumentów, maszyn itp., których używa się rzadko lub wcale. Słowem kluczowym jest „usuń”;

- $\quad$ systematyka: przechowywanie potrzebnych rzeczy we właściwym miejscu w systematyczny i uporządkowany sposób, tak aby te najczęściej używane znalazły się w zasięgu ręki;

- $\quad$ sprzątanie: utrzymywanie czystości i porządku w miejscu pracy oraz jego otoczeniu;

- standaryzacja: jest to codzienne wykonywanie trzech pierwszych kroków $5 S$, ustalenie czytelnych i jasnych dla wszystkich zasad i procedur postępowania;

\footnotetext{
${ }^{5}$ P. Miller, Systemowe zarządzanie jakością, Difin, Warszawa 2011, s. 447.

${ }^{6}$ D. Zimon, Ł. Gawron-Zimon, Wykorzystaniem etody QFDdo doskonalenia logistycznej obstugi klienta, [w:] Innowacjewzarzadzaniu i inżynierii produkcji, red. R. Knosala, Oficyna Wydawnicza Polskiego Towarzystwa Zarządzania Produkcją, Opole 2014, s. 1078.

${ }^{7}$ J. Łunarski, Zarządzanie jakościa w logistyce, Oficyna Wydawnicza Politechniki Rzeszowskiej, Rzeszów 2012, s. 12.

${ }^{8}$ T. Osada, The 5-S's - Five Keys to a Total Quality Environment, OPO, Tokyo 1991, s. 5.

${ }^{9}$ D. Zimon, Zarzqdzanie jakościa w logistyce, CeDeWu, Warszawa 2013, s. 104.
} 
- $\quad$ samodyscyplina: wyrobienie w sobie nawyku przestrzegania tych zasad, najważniejsze jest zaangażowanie oraz reagowanie na każde odstępstwo od reguł $5 \mathrm{~S}$

Niektórzy autorzy wzbogacają zasadę 5S o szóste „S” (Safety - bezpieczeństwo), które należy interpretować jako bezpieczną pracę w bezpiecznym środowisku ${ }^{10}$.

\section{IMPLEMENTACJA ZASAD 5S W MAGAZYNIE WYROBÓW GOTOWYCH}

Proces wdrażania praktyk 5S w analizowanym przedsiębiorstwie wspierał i nadzorował zespół wdrażający, w którego skład wchodzili Dyrektor Zakładu, przedstawiciele kadry kierowniczej oraz specjaliści. Każdy obszar miał swojego lidera odpowiedzialnego za prawidłową realizację zidentyfikowanych procesów. W badanym przedsiębiorstwie zasadami $5 \mathrm{~S}$ zostały objęte procesy produkcyjne i magazynowe. W publikacji (ze względu na ograniczone miejsce) zostanie dokładniej omówione jedynie funkcjonowanie zasad $5 \mathrm{~S}$ w Magazynie Wyrobów Gotowych, gdzie dokonuje się kompletacji i wysyłki towarów. W pozostałych obszarach przedsiębiorstwa metoda ta funkcjonuje podobnie.

Implementacja zasad 5S przebiegała według schematu zaprezentowanego na rysunku 1.

Rys. 1. Schemat implementacji zasad 5S

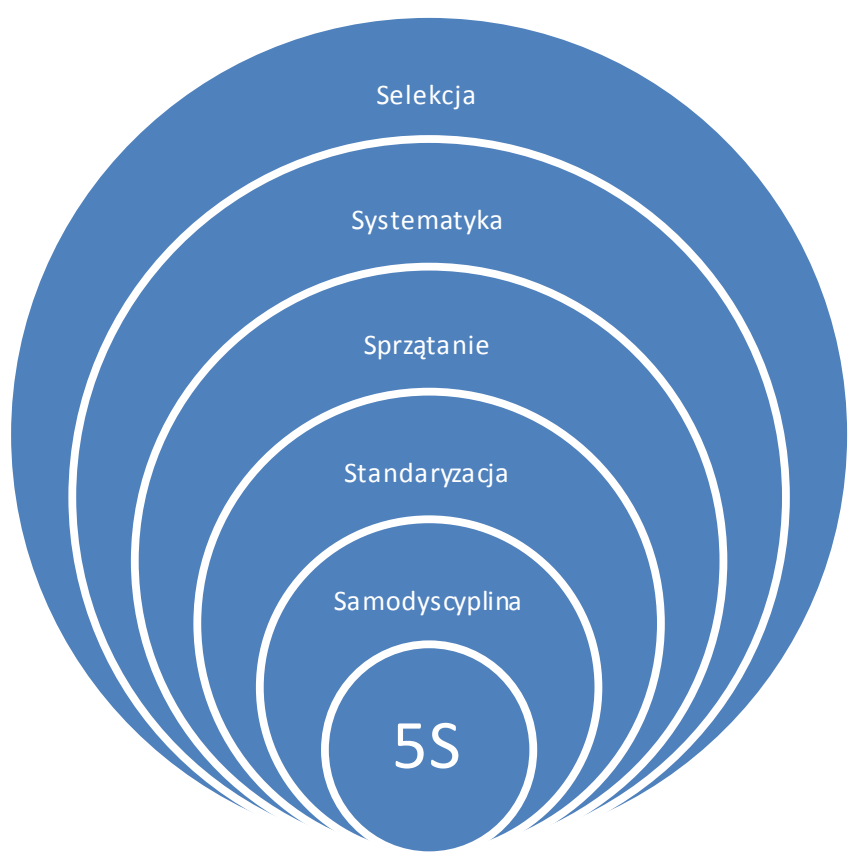

Źródło: opracowanie własne.

${ }^{10}$ A. Gazda, D. Malindžák, Logistic process quality assessment, „TRANSPORT \& LOGISTICS” 2012/25, s. 7. 
Każdy krok praktyk 5S wdrażano według następującego harmonogramu:

- $\quad$ szkolenie pracowników;

- lekcja tematyczna dotyczące bieżącego „S”;

- prowadzenie działań przewidzianych w danym kroku;

- audyt;

- rozpoczęcie wdrażania kolejnego kroku;

- $\quad$ kontrola poprzedniego kroku i działania doskonalące.

W ramach Selekcji pracownicy mieli za zadanie krytycznie ocenić swoje stanowisko pracy w celu wyselekcjonowania wszystkich rzeczy, które nie są potrzebne na co dzień. Kierowano się przy tym zasadami: pozostaje tylko to, co jest niezbędne, tylko tyle, ile potrzeba, tylko wtedy, kiedy trzeba, oraz zasadą: jeśli masz wątpliwość - wyrzuć. Na każdy z niepotrzebnych przedmiotów naklejano czerwoną kartkę. Podczas oklejania odpowiadano sobie na pytania:

- $\quad$ Czy ta rzecz jest potrzebna?

- Jeśli jest potrzebna, to czy w takiej ilości?

- Jeśli jest potrzebna, to czy na pewno musi być właśnie tu?

Oklejone przedmioty trafiły $\mathrm{w}$ jedno wyznaczone miejsce. Postępowano $\mathrm{z}$ nimi w sposób przedstawiony na rysunku 2. Był to stosunkowo prosty krok. Pracownicy po zapoznaniu się z lekcją tematyczną dotyczącą Selekcji z łatwością poradzili sobie z wyeliminowaniem zbędnych przedmiotów. W razie wątpliwości pomocy udzielali specjaliści oraz pozostali członkowie zespołu wdrażającego.

Rys. 2. Sposób postępowania z przedmiotami oznaczonymi czerwoną kartką

\section{Co robimy z rzeczami?}

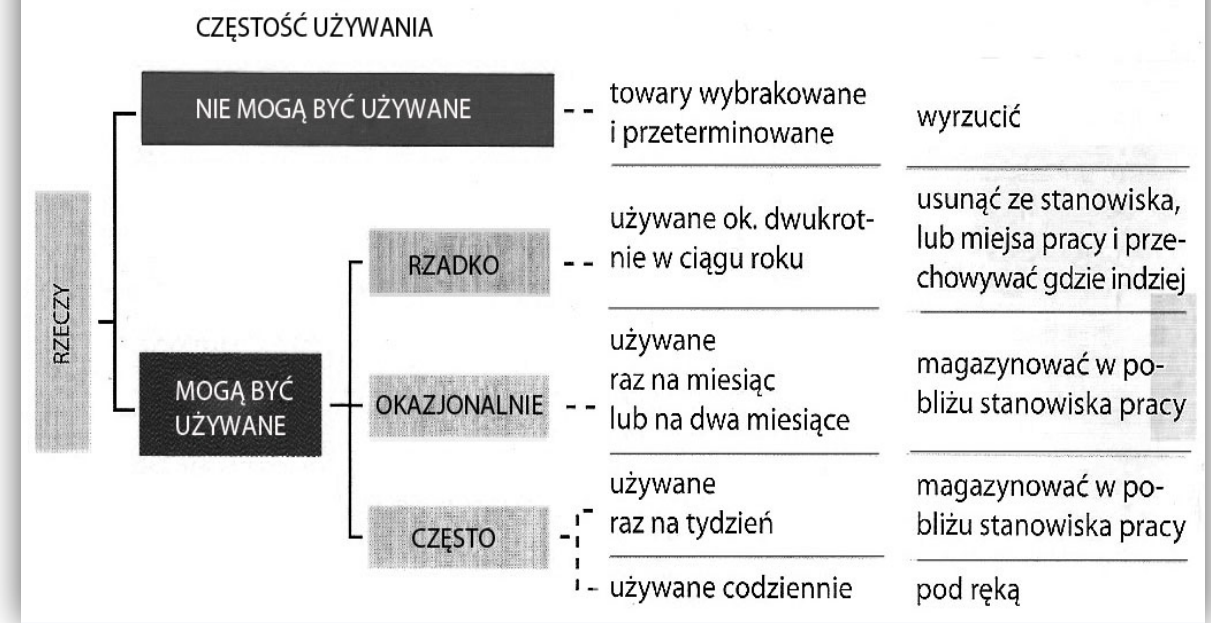

Źródło: opracowanie własne 
Podczas realizacji drugiego kroku określono sposób i odpowiednie miejsca składowania elementów niezbędnych do wykonywania pracy na danym stanowisku roboczym. Zaczęto od spisu przedmiotów z danego stanowiska pracy i określenia, jak często dane narzędzia są używane. Następnie wybrano miejsce dla każdego z przedmiotów i odpowiednio je oznaczono. Pracownicy mieli za zadanie zadbać o to, aby przepływ materiałów i dokumentów usprawniał realizowane procesy. Ponadto zaprojektowano i wykonano tablice cieni, które zostały umieszczone w tzw. kącikach czystości. Usystematyzowano gospodarowanie odpadami poprzez użycie przyjętego oznakowania. Zastosowano także znakowanie kolorami: żółty - ciągi komunikacyjne i pola relacyjne na podłogach i posadzkach; czerwony - przeszkody, butle gazowe; zielony - wagi, parkingi, kosze na śmieci.

Zgodnie z wytycznymi dotyczącymi Sprzątania pracownicy zostali zobowiązani do utrzymywania czystości swojego miejsca pracy ze szczególnym uwzględnieniem rzeczy magazynowych (surowce, materiały, opakowania), wyposażenia (wózki, narzędzia ręczne, narzędzia pomiarowe, formy, pojemniki, meble) i pomieszczeń (podłogi, obszary robocze, drogi, ściany, filary, okna, toalety, pomieszczenia biurowe i socjalne). Dodatkowo pracownicy zostali uczuleni na to, aby każde sprzątanie było jednocześnie przeglądem, którego celem było skorygowanie ewentualnych odchyleń od przyjętych standardów.

Standaryzację wykorzystano do ustalenia czytelnych i jasnych dla wszystkich zasad i procedur postępowania. Opracowano tak zwane karty standaryzacyjne klarownie określające, jak dane stanowisko pracy powinno wyglądać. Pomocne okazały się one w początkowym okresie implementacji 5S, kiedy to pracownicy dopiero uczyli się dobrych praktyk związanych z pierwszymi trzema krokami.

Samodyscyplina była etapem najtrudniejszym do zaakceptowania przez kadrę pracowniczą. Wymaga ona bowiem, aby utrzymywanie porządku i czystości w miejscu pracy stało się normą dla wszystkich. W celu zwiększenia Samodyscypliny wykorzystano takie narzędzia, jak: plakaty, fotografie ,przed i po", tablice 5S, lekcje jednotematyczne itp. Ważną rolę odegrały również działania motywacyjne ze strony najwyższego kierownictwa.

Wdrożenie metody $5 \mathrm{~S}$ ma na celu pomoc organizacji w łatwiejszej i wydajniejszej pracy. Trzeba jednak pamiętać, że nie może ono być działaniem jednorazowym. Aby praktykowanie zasad 5S było procesem ciągłym przeprowadzane są regularne audyty. Początkowo odbywały się one co tydzień. Obecnie przeprowadzane są raz w miesiącu. Zespół audytorów składa się z koordynatora 5S, lidera obszaru oraz wybranego pracownika. Do przeprowadzenia audytu służy specjalnie wypracowany formularz. Pytania dotyczące poszczególnych elementów metody 5S zaprezentowano w tabeli 1. 
Tabela 1. Przykładowe py tania doty czące audy tu

\begin{tabular}{|c|c|}
\hline \multirow{4}{*}{ Selekcja } & Czy są niepotrzebne przedmioty, materiały, narzẹdzia? \\
\hline & Czy są rzeczy w nadmiemej ilości? \\
\hline & $\begin{array}{l}\text { Czy materiały są identyfikowalne (posiadają kartẹ identyfikacyjną z } \\
\text { danymi takimi jak: ilość, indeks, data wykonania)? }\end{array}$ \\
\hline & $\begin{array}{l}\text { Czy sprzęt wykorzystywany do prac jest uporządkowany } \\
\text { i wykorzystywany do bieżących potrzeb? }\end{array}$ \\
\hline \multirow{4}{*}{ Systematyka } & Czy drogi i przejścia są oznakowane i wolne? \\
\hline & Czy materiały i narzędzia mają wyznaczone, oznakowane miejsca? \\
\hline & Czy pracownicy stosują się do środków ochrony osobistej? \\
\hline & Czy materiały i narzędzia są w przeznaczonych miejscach? \\
\hline \multirow{4}{*}{ Sprzątanie } & Czy materiały do sprzątania są dostępne? \\
\hline & Czy posadzka utrzymana jest w czystości? \\
\hline & $\begin{array}{l}\text { Czy maszyny, urządzeniai oprzyrządowanie składowane w obrẹbie strefy } \\
\text { są utrzymane w czystości? }\end{array}$ \\
\hline & Czy pojemniki na śmieci nie są przepełnione? \\
\hline \multirow{4}{*}{ Standaryzacja } & Czy stany magazynowe są zgodne z I.F.S.? \\
\hline & $\begin{array}{l}\text { Czy palety, pojemniki, kartony, są ustawione prawidłowo są pozamykane, } \\
\text { towary zabezpieczone przed uszkodzeniem? }\end{array}$ \\
\hline & Czy checklisty działań $5 \mathrm{~S}$ istmieją i są wypehnione? \\
\hline & Czy zdefiniowane procedury i instrukcje stanowiska są przestrzegane? \\
\hline \multirow{4}{*}{ Samodyscyplina } & Czy przestrzegane są zasady i dyscyplina 5S? \\
\hline & Czy pracownicy zgłaszają wnioski dot. poprawy obszarów pod kątem $5 \mathrm{~S}$ ? \\
\hline & Czy realizowane są zadania wynikające z Planu poprawy $5 \mathrm{~S} / \mathrm{OE} / \mathrm{FTQ}$ ? \\
\hline & $\begin{array}{l}\text { Czy pracownicy utrzymują poprawny lub korygują negatywny trend } \\
\text { poprzednich audytów } 5 \mathrm{~S} \text { ? }\end{array}$ \\
\hline
\end{tabular}

Żródło: opracowanie własne

Wszystkie pytania oceniane są w skali 0-2. Maksymalnie w ramach każdego z pięciu „S” można uzyskać 8 punktów. Każdy audyt kończy się podsumowaniem, informacją zwrotną dla lidera obszaru dotyczącą elementów pozytywnych i tych wymagających rozwoju. W razie potrzeby przeprowadzane są działania korygujące. Wyniki przedstawiane są wszystkim pracownikom w formie wykresu. Sprawnie przeprowadzone audyty 5S mogą być bardzo skutecznym sposobem na zanik przestrzegania standardów oraz malejące zaangażowanie w działania rozwijające potencjał organizacji.

DALSZE DZIALANIA DOSKONALĄCE

Wdrożenie zasad 5S w Magazynie Wyrobów Gotowych usprawniło procesy magazynowe oraz pozwoliło na wyeliminowanie sporej liczby wadliwych wysyłek, jednak problem reklamacji logistycznych nie został całkowicie rozwiązany. Przyczyną reklamacji w głównej mierze były błędy popełniane podczas kompletacji zamówień oraz załadunku towarów, takie jak:

- $\quad$ pobranie towaru ze złej lokalizacji magazynowej;

- błędne skompletowanie towaru, nieodpowiednia ilość lub asortyment; 
- niewłaściwe przygotowanie skompletowanego towaru do wysyłki (błędny adres, etykieta logistyczna itp.);

- załadowanie na środek transportu palety z innego zamówienia;

- niedołączenie dokumentacji do zamówienia;

- pominięcie palety podczas załadunku itd.

W celu wyeliminowania reklamacji logistycznych oraz usprawnienia procesu kompletacji i wysyłki opracowano plan reorganizacji części Magazynu Wyrobów Gotowych, gdzie znajduje się pole kompletacyjne oraz odbywa się załadunek. Na rysunku 3 przedstawiono uproszczony plan Magazynu Wyrobów Gotowych zgodny ze stanem pierwotnym, natomiast na rysunku 4 - projekt po zastosowaniu reorganizacji placu kompletacyjnego. Użyto następujących oznaczeń:

- Z - załadunkowy;

- $\mathrm{K}$ - kompletujący;

- W - wózkowy, zwożący;

- Komp - stanowisko komputerowe wraz z drukarką;

- $\mathrm{R}$ - regały;

- A1-A8 - rampy załadunkowe.

Rys. 3. Plan magazynu przed zastosowaniem zmian

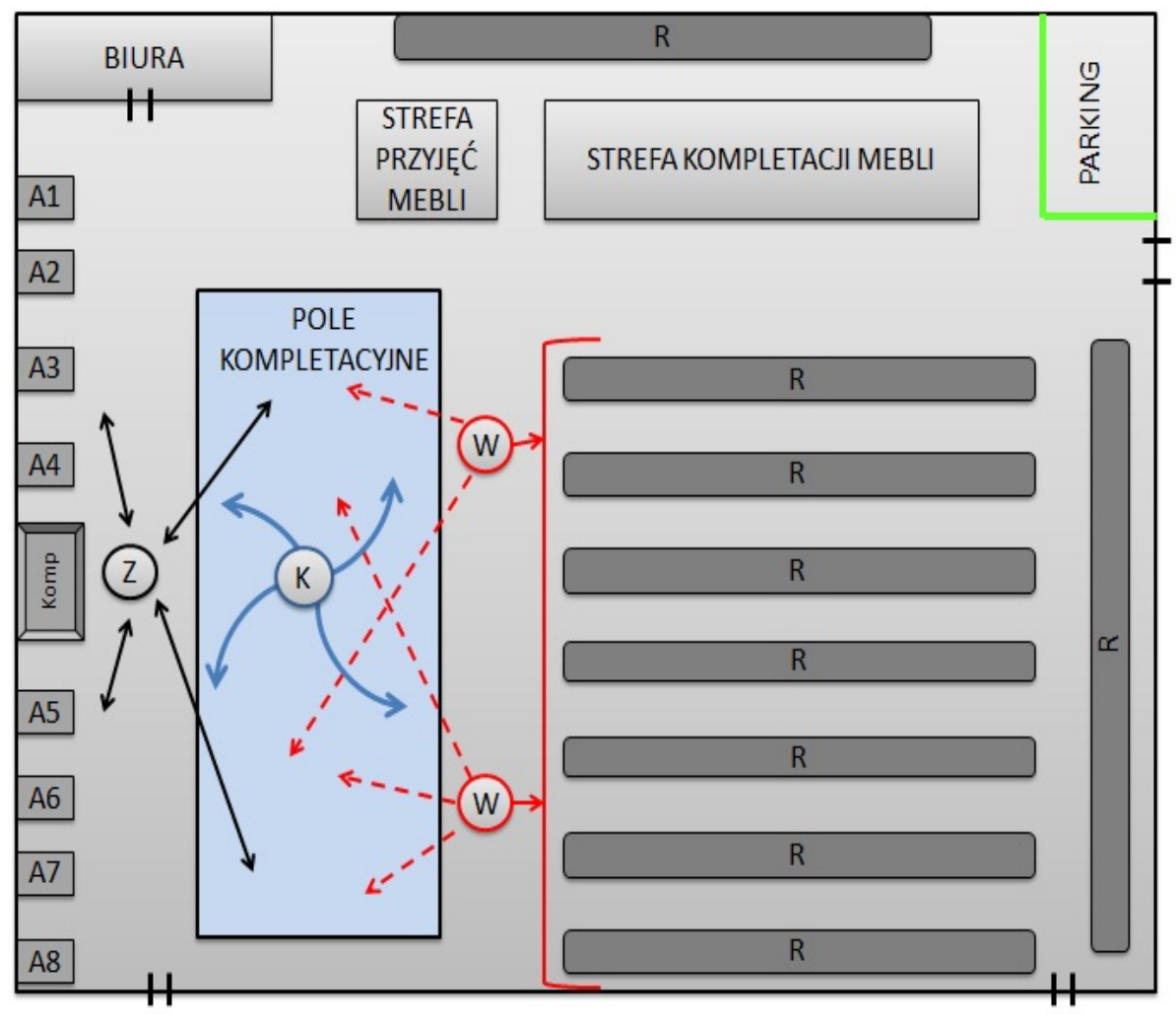

Źródłó: opracowanie własne 
Dokonując analizy rysunku, można zauważyć, że operator wózka zwozi towary zgodnie z listą załadunkową i odkłada je w polu kompletacyjnym w wolnym na daną chwilę miejscu. Palety układane są tak, aby do każdej z nich był dostęp. Kompletujący sprawdza poprawność skompletowanego zamówienia i przygotowuje je do wysyłki, po czym ,przesuwa” w dowolnie wybrane miejsce. Powstaje w ten sposób chaos, który prowadzi do pomyłek zarówno przy kompletacji, jak i załadunku. W celu usprawnienia procesu kompletacji i wysyłki zamówień zaproponowano wprowadzenie zmian w organizacji pola kompletacyjnego (rys. 4), które miałyby przebiegać następująco:

- podzielenie istniejącego PK na dwie równe części przedzielone ciągiem komunikacyjnym - uzyskanie dwóch niezależnych pól kompletacyjnych. PK1 obsługuje rampy A1-A4, PK2 rampy A5-A8;

- oznaczenie granic PK1 i PK2 liniami w kolorze żółtym;

- naniesienie znaków pionowych „PK1” oraz „PK2” - symbole mają znajdować się od strony regałów przed liniami wyznaczającymi granice pól kompletacyjnych;

- $\quad$ podzielenie każdego z PK na dwie części:

- strefę kompletacji (SK), gdzie skompletowany towar będzie sprawdzany

i przygotowywany do wysyłki,

- strefę wysyłki (SW), gdzie towar gotowy do wysyłki czeka na załadunek,

- przy czym SK ma być dwukrotnie większa od SW;

- $\quad$ pomalowanie powierzchni SW na niebiesko - ma to zapobiec zacieraniu się granicy między SK i SW;

- wyposażenie PK1 i PK2 w narzędzia i materiały potrzebne do przygotowania towaru do wysyłki;

- $\quad$ poprowadzenie zielonej ciągłej linii wzdłuż ramp od A1 do A4 oraz od A5 do A8 - wyodrębnienie obszaru do dyspozycji załadunkowego;

- $\quad$ poprowadzenie zielonej przerywanej linii pomiędzy A4 i A5 - umożliwienie pracownikom magazynowym dostęp do IFS oraz drukarki etykiet;

- umieszczenie tablicy informacyjnej na ścianie obok wejścia do Biura - na tablicy powinny się znaleźć, zgodnie z rozpiską, informacje dotyczące kierunku, planowanej godziny załadunku oraz rampy, na którą podstawi się dany samochód. Tablica powinna być dobrze widoczna z PK1 oraz PK2. 
Rys. 4. Plan magazynu po wprowadzeniu zmian

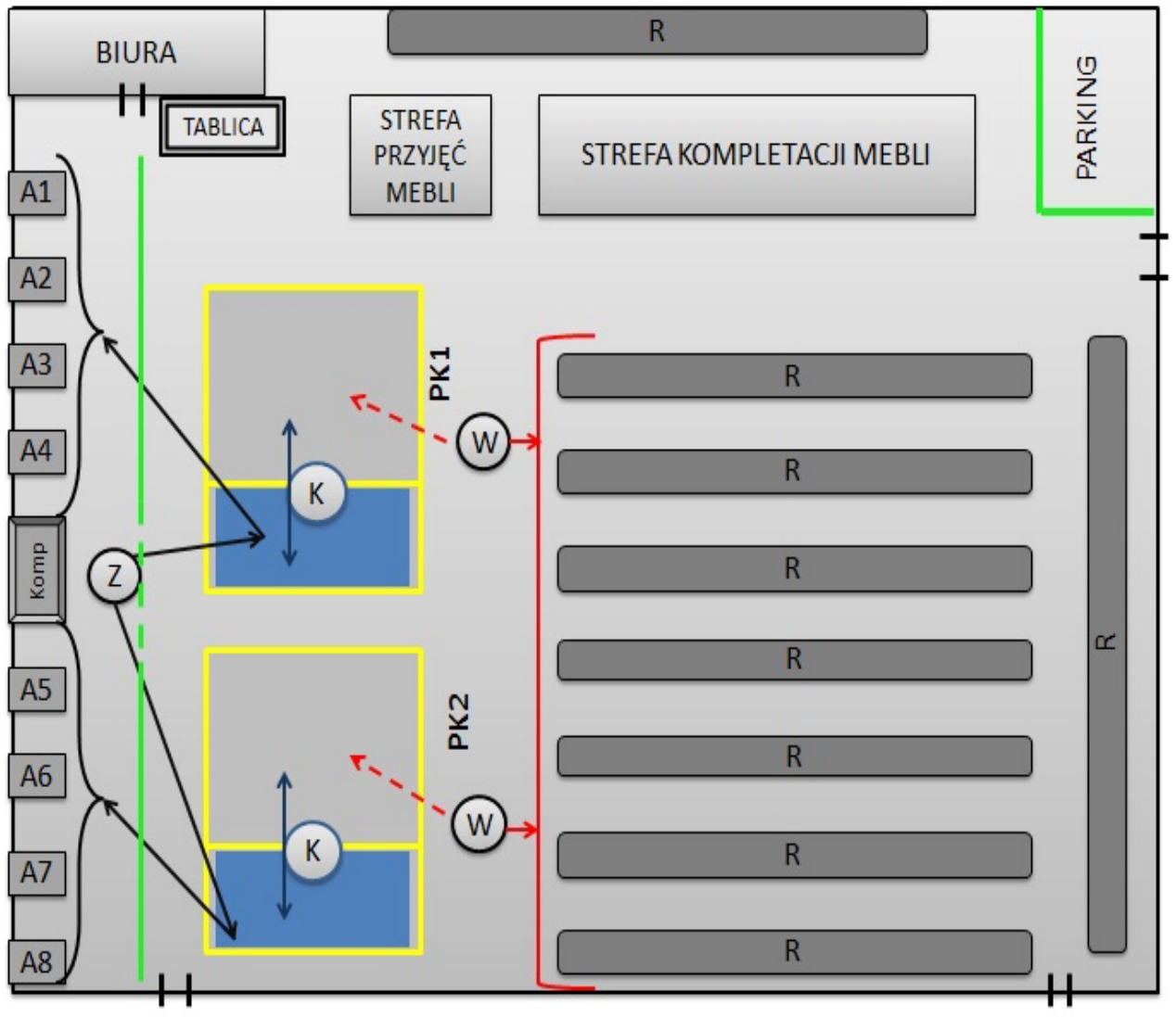

Źródło: opracowanie własne.

Po wdrożeniu planu reorganizacji placu kompletacyjnego każdy z pracowników ma ściśle określoną strefę działania, dzięki czemu liczba pomyłek powinna zostać zminimalizowana, a reklamacje logistyczne przynajmniej częściowo wyeliminowane. W celu utrwalenia zaproponowanych zmian opracowano procedurę regulującą zachowania pracowników podczas procesu kompletacji i załadunku towarów.

\section{PODSUMOWANIE}

Implementacja zasad 5S w organizacji nie wymaga dużych nakładów. Jest to system prosty i zrozumiały, a wprowadzony porządek w krótkim czasie może przynieść wymierne korzyści. Praca na stanowiskach staje się mniej męcząca dla pracownika i bardziej efektywna. Do najczęściej zauważanych korzyści wynikających z wdrożenia zasad 5S zalicza się ${ }^{11}$ :

\footnotetext{
${ }^{11}$ M. Niewczas, Audit systemu 5-S, ,Problemy Jakości” 2010/4, s. 24; D. Zimon, Instrumentarium zarządzania jakościa, „Zarządzanie i Marketing” 2011/2, s. 239.
} 
- usprawnienie procesów i płynności pracy;

- ukierunkowanie projakościowe;

- wzrost terminowości;

- redukcję zbędnych działań;

- $\quad$ poprawę higieny i bezpieczeństwa pracy;

- usprawnienie komunikacji;

- redukcję liczby defektów i wypadków;

- $\quad$ wzrost produktywności i jakości wykonywanych działań;

- krótszy czas przezbrajania maszyn;

- eliminację marnotrawstwa.

$\mathrm{Na}$ przykładzie przeprowadzonych analiz można jednoznacznie stwierdzić, że 5S pozytywnie wpływa na doskonalenie działań i czynności w obrębie magazynu wyrobów gotowych. Prace zostały usprawnione, uporządkowane oraz zredukowano liczbę błędów i pomyłek.

Kluczem do sukcesu jest wdrożenie zasad 5S w ten sposób, aby stanowiska robocze stawały się z dnia na dzień coraz bardziej przyjazne zarówno z punktu widzenia estetyki, jak również z punktu widzenia ergonomii i organizacji pracy. Pozwoli to nie tylko załodze sprawniej wykonywać swoje obowiązki, ale również identyfikować się z organizacją oraz przełoży się na wzrost satysfakcji pracowników. Dość często zdarza się sytuacja, w której pracownicy po wdrożeniu zasad $5 \mathrm{~S}$ czuli się wyróżnieni, pracując - według informacji od nich uzyskanych - ,na najładniejszych i najnowocześniejszych stanowiskach pracy w fabryce!”.

Podkreślić należy również, że implementacja zasad 5S (jak i wszelkich nowych rozwiązań) musi być przez pierwsze lata stale monitorowana i doskonalona. W pierwszych miesiącach ,zakorzeniania” się zasad 5S w organizacji może się pojawić bowiem opór i niechęć pracowników do regularnego stosowania się do nowych wytycznych. Dlatego bardzo istotna jest kwestia nadzoru oraz działań motywacyjnych, szczególnie ze strony liderów i kierownictwa organizacji.

Podsumowując, warto nadmienić, że implementację zasad 5S obecnie traktuje się jedynie jako fundament, na którego bazie będą podejmowane kolejne kroki prowadzące do udoskonalania sposobów zarządzania przedsiębiorstwem (rys. 5.). 
Rys. 5. Rozwój koncepcji 5S

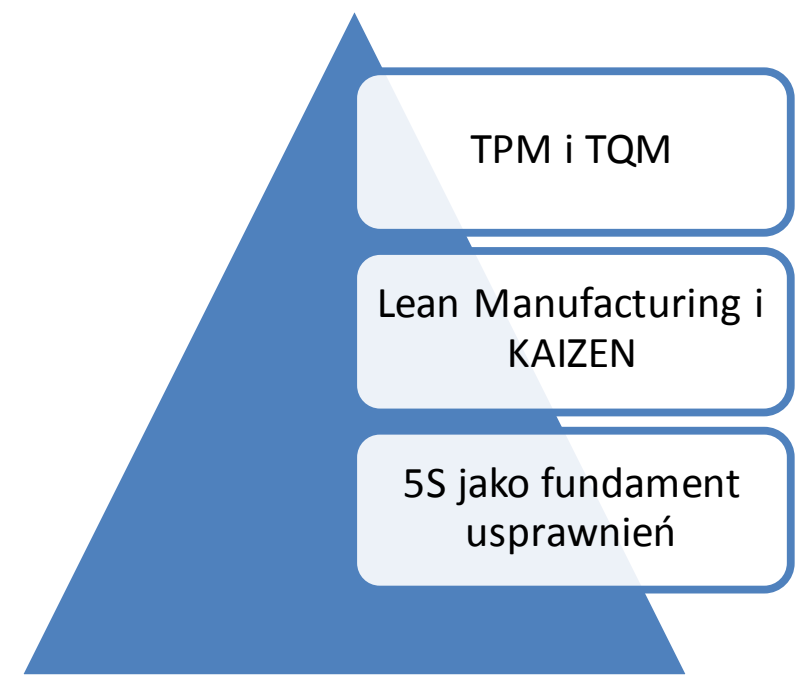

Źródło: opracowanie własne.

Dalsze działania powinny być ukierunkowane na wdrażanie zasad Lean Manufacturing oraz koncepcji Kaizen, które usprawniają najważniejsze procesy w organizacji, skupiają się na minimalizacji błędów, bazują na ciągłym doskonaleniu, pracy zespołowej oraz pobudzają kadrę zarządzającą i szeregowych pracowników do kreowania jakości.

\section{LITERATURA}

[1] Ciesielski M., Instrumenty zarządzania łańcuchami dostaw, PWE, Warszawa 2009, s. 31.

[2] Gazda A., Malindžák D., Logistic process quality assessment, „TRANSPORT \& LOGISTICS” 2012/25, s. 7.

[3] Łunarski J., Zarządzanie jakościa w logistyce, Oficyna Wydawnicza Politechniki Rzeszowskiej, Rzeszów 2012, s. 12.

[4] Miller P., Systemowe zarządzanie jakością, Difin, Warszawa 2011, s. 447.

[5] Niewczas M., Audit systemu 5-S, „Problemy Jakości” 2010/4, s. 24.

[6] Osada T., The 5-S's - Five Keys to a Total Quality Environment, OPO, Toky o 1991, s. 5.

[7] Zimon D., Gawron-Zimon Ł., Wykorzystanie metody QFD do doskonalenia logistycznej obstugi klienta, [w:] Innowacje w zarządzaniu i inżynierii produkcji, red. R. Knosala, Oficyna Wydawnicza Polskiego Towarzystwa Zarzadzania Produkcją, Opole 2014, s. 1078.

[8] Zimon D., Instrumentarium zarządzania jakościa, „Zarządzanie i Marketing” 2011/2, s. 239.

[9] Zimon D., Zarządzanie jakościq w logistyce, CeDeWu, Warszawa 2013, s. 104.

\section{IMPACT OF IMPLEMENTING 5S RULES FOR IMPROVING WAREHOUSE PROCESS- ES IN THE SELECTED ORGANIZATION}

There are now many specific methods and tools of quality management to improve both logistics and production operations, one of them is undoubtedly the concept of 5S. The idea 
behind the establishment of $5 \mathrm{~S}$ and the maintenance of order and discipline in place (on the position) of work. 5S practices are one of the cornerstones of creating a work environment conducive to quality improvement, harmonious work and continuous improvement of human relations, which translates to the efficiency of the organization. $5 \mathrm{~S}$ is one of the most important elements of good governance. The purpose of this publication is to show to what extent the implementation of the principles of $5 \mathrm{~S}$ can affect the improvement of logistics activities in the area of inventory management in selected manufacturing organization. When analyzing the literature and studying the process of implementing the principles of $5 \mathrm{~S}$ in the selected organization it was stated that the implementation of the principles of $5 \mathrm{~S}$ in the enterprise does not require large expenditure. That is a simple and understandable system, and entered the order in a short time can bring tangible benefits. Themost noticeable benefits that arise from the implementation of $5 \mathrm{~S}$ principles include: streamlining processes and liquidity jobs, increase the timeliness, reducing unnecessary interventions, improving health and safety, improving communication, reducing the number of defects and accidents. It was also highlighted that the implementation of the principles of 5S must be in the early years continuously monitored and updated.

Keywords: 5S, quality, logistics, tools

DOI: $10.7862 /$ rz.2014.mmr.28

Tekst złożono w redakcji: maj 2014

Przyjęto do druku: czerwiec 2014 